\title{
Clinical Features and Disease Management in Adult Patients With Atopic Dermatitis Receiving Care at Reference Hospitals in Brazil: the ADAPT Study
}

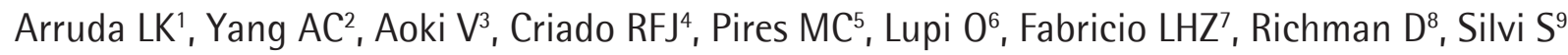 \\ ${ }^{1}$ Ribeirão Preto Medical School, University of São Paulo, Ribeirão Preto, São Paulo, Brazil \\ ${ }^{2}$ Hospital das Clínicas da Faculdade de Medicina da Universidade de São Paulo (USP), Disciplina de Imunologia Clínica e Alergia, São Paulo, Brazil \\ ${ }^{3}$ Hospital das Clínicas da Faculdade de Medicina da USP, Departamento de Dermatologia, São Paulo, Brazil \\ ${ }^{4}$ Faculdade de Medicina do ABC, São Paulo, Brazil \\ ${ }^{5}$ Hospital do Servidor Público Estadual; Hospital Padre Bento, São Paulo, Brazil \\ ${ }^{6}$ Universidade Federal do Rio de Janeiro (UFRJ); Universidade Federal do Estado do Rio de Janeiro (UNIRIO); Policlínica Geral do Rio de Janeiro \\ (PGRJ), Rio de Janeiro, Brazil \\ ${ }^{7}$ Hospital Universitário Evangélico de Curitiba da Faculdade Evangélica do Paraná (HUEC/FEPAR), Paraná, Brazil \\ ${ }^{8}$ Sanofi Genzyme, Cambridge, USA \\ 'Sanofi Genzyme, São Paulo, Brazil
}

J Investig Allergol Clin Immunol 2021; Vol. 31(3): 236-245

doi: 10.18176/jiaci.0478

\begin{abstract}
Background: Atopic dermatitis is a chronic inflammatory skin disease with a prevalence of $0.02 \%$ to $8.1 \%$ in adults. Adult patients with moderate-to-severe atopic dermatitis are affected by frequent relapses and a significant disease burden.

Objective: To determine the clinical, immunological, and therapeutic profile of Brazilian adults with atopic dermatitis.

Methods:A multicenter, observational, retrospective, descriptive registry-based study was conducted at reference hospitals between December 2016 and October 2017. The data collected were demographics, personal and family history of atopic diseases, clinical manifestations, laboratory tests, disease severity and management.

Results: Of the 187 patients included in the analysis, $56.1 \%$ were female and $71.7 \%$ were White, with a mean age of 24.7 years. Mean follow-up was 9 years. Asthma or other allergic diseases were reported by $80.2 \%$ of patients. The main comorbidity was hypertension $(10.2 \%)$, and common disease manifestations included pruritus and erythema. Lesions generally affected flexural and nonflexural areas, with typical morphology. Around $83 \%$ of patients had moderate-to-severe disease, and $8.6 \%$ reported at least 1 hospitalization. Most patients received topical and/or systemic pharmacological therapies, including omalizumab (5.9\%); $4.3 \%$ received phototherapy. Moreover, $66.8 \%$ of patients received adjuvant therapy, and $79.1 \%$ changed or discontinued treatment for atopic dermatitis due to remission (46.5\%), poor effectiveness (33.7\%), or lack of adherence (12.9\%). Most patients presented characteristics of type 2 inflammation, with immunoglobulin E levels above $100 \mathrm{lU} / \mathrm{mL}$ (94.4\%) and peripheral blood eosinophils above $5 \%$ (55.9\%).

Conclusion: Brazilian adult patients with severe atopic dermatitis need treatment to efficiently control the disease and improve quality of life. Key words: Atopic dermatitis. Epidemiologic study characteristics. Disease management. Adult. Tertiary care centers.
\end{abstract}

\section{Resumen}

Antecedentes: La dermatitis atópica es una enfermedad inflamatoria crónica de la piel con una prevalencia, en adultos, del 0,02\% al $8,1 \%$. Los pacientes adultos con dermatitis atópica moderada o grave tienen reagudizaciones frecuentes y una sintomatología importante. Objetivos: Describir las características clínicas e inmunológicas, así como las opciones terapéuticas de los pacientes brasileños adultos con dermatitis atópica.

Métodos: Estudio multicéntrico, observacional, retrospectivo, descriptivo y basado en registros, realizado en hospitales de referencia, entre diciembre de 2016 y octubre de 2017. Se recopilaron datos demográficos, antecedentes personales y familiares de enfermedades atópicas, manifestaciones clínicas, pruebas de laboratorio, gravedad y manejo de la enfermedad.

Resultados: De los 187 pacientes incluidos en el análisis, el 56,1\% fueron mujeres y el 71,7\% caucásicos, con una edad media de 24,7 años. La duración media del seguimiento fue de 9 años. El 80,2\% de los pacientes referían asma u otras enfermedades alérgicas. La principal comorbilidad fue la hipertensión $(10,2 \%)$ y las manifestaciones más frecuentes de la enfermedad fueron el prurito y el eritema. Las lesiones se distribuyeron tanto en flexuras como en áreas no flexurales, con una morfología típica. Alrededor del $83 \%$ de los pacientes tenían enfermedad moderada a grave y el 8,6\% notificó al menos una hospitalización. La mayoría de los pacientes recibieron tratamientos 
farmacológicos tópicos y/o sistémicos, incluyendo omalizumab (5,9\%). El 4,3\% recibió fototerapia. Además, el 66,8\% de los pacientes recibió terapia adyuvante y el 79,1\% cambió o suspendió el tratamiento para la dermatitis atópica debido a la remisión (46,5\%), poca efectividad $(33,7 \%$ ) o falta de adherencia terapéutica (12,9\%). La mayoría de los pacientes presentaron características de inflamación tipo 2, con niveles de inmunoglobulina E superiores a $100 \mathrm{UI} / \mathrm{ml}(94,4 \%$ ) y cifras de eosinófilos en sangre periférica superiores al 5\% (55,9\%). Conclusión: Los pacientes brasileños adultos con dermatitis atópica necesitan tratamiento continuo para controlar la enfermedad de manera eficiente y mejorar la calidad de vida.

Palabras clave: Dermatitis atópica. Adulto. Estudio epidemiológico. Tratamiento. Hospital terciario.

\section{Introduction}

Atopic dermatitis (AD) is a chronic inflammatory disease with an estimated global prevalence of $0.02 \%-8.1 \%$ in adults [1-4]. Epidemiologic data show that the prevalence, clinical presentation, and severity of AD vary between different populations, as does access to health care and treatment. These variations reflect multifactorial interactions between genetic, immune, and environmental features of the disease [3-8].

As a predominantly pediatric dermatosis, $\mathrm{AD}$ and the burden it generates during adolescence and early adulthood are poorly characterized. This disease can be persistent, with an early onset or first manifest late during adulthood [2,9]. Adult patients with moderate-to-severe AD may have frequent recurrences, with a marked impact on quality of life, affecting personal, family, and social dimensions [10].

In Brazil, a comprehensive characterization of the adult population with AD is limited. Three Brazilian studies described the profile of adults with skin disorders and the impact of their disease on quality of life [11-13] and found that both patient journey and disease management are very challenging. Adult patients with AD present heterogeneous and relapsing-remitting disease due to triggering factors, infections (eg, by Staphylococcus aureus), and other allergic/ atopic comorbidities (eg, asthma) [14-15].

Clinical guidelines for diagnosis and treatment of $\mathrm{AD}$ have been published in Brazil [16,17]. Relapses can be controlled with topical corticosteroids and calcineurin inhibitors, in addition to adjuvant treatment for pruritus [18]. Second-line therapies include phototherapy and systemic immunosuppressants (eg, oral cyclosporine, methotrexate). Recently, immunobiological and targeted disease-modifying therapies were developed to provide effective control of moderate-to-severe AD [19,20].

Hence, it is crucial to understand the clinical course of $\mathrm{AD}$ and how to improve its management in adults, especially those with refractory forms of the disease. This epidemiological registry-based study aimed to examine the clinical, immunological, and therapeutic characteristics of adult patients with $\mathrm{AD}$ receiving care at tertiary institutions in Brazil.

\section{Methods}

\section{Patients and Study Design}

This multicenter, observational, retrospective, descriptive registry-based study was conducted between December 2016 and October 2017. Adult participants with AD were followed in 7 reference hospitals in southern and southeastern Brazil (Paraná, São Paulo, and Rio de Janeiro). Data were collected from the medical records of patients who had been receiving care at the hospital for at least the previous 36 months. The selection criteria required that participants had attended at least 3 visits to the site during the retrospective study period, including the admission visit (designated as the first visit), an intermediate follow-up visit during the previous 36 months, and a final visit within the 12 months before entering the study (designated as the last visit). The local ethics committees approved the study protocol, and all procedures complied with the Declaration of Helsinki and Good Epidemiological Practices. Eligible patients who met the selection criteria described in Table 1 were enrolled retrospectively and consecutively to minimize possible selection bias.

\section{Study Outcomes}

The primary outcome measure was the distribution of demographic and clinical features and disease management of adult $\mathrm{AD}$ patients who had received care within the previous 36 months at the participating sites. Data were retrospectively collected, as follows: demographics (age, sex, and ethnicity); personal and family history of $\mathrm{AD}$; and clinical characteristics

Table 1. Selection Criteria for Patients in the ADAPT Study

Inclusion Criteria

- Age $>18$ years (at enrollment)

- Participants receiving care at the hospital in the previous 36 months (at least)

- Diagnosis of AD in the previous 36 months

- Participants who attended at least 3 visits to the site during the retrospective study period (ie, admission visit, intermediate follow-up visit during the last 36 months, and a final visit within 12 months before study entry)

Exclusion Criteria

- Other severe skin conditions not related to AD that may have affected $\mathrm{AD}$ management (according to investigator criteria)

- Primary or secondary immunodeficiency with skin manifestations similar to $\mathrm{AD}$

- Patients who participated in clinical trials during the last 36 months that may have affected management of AD 
(age of onset, lesion distribution and morphology, comorbidities and/or laboratory changes, manifestations, and severity).

We assessed the severity of AD by applying the following scores: SCORing Atopic Dermatitis (SCORAD), 5-point Investigator's Global Assessment (IGA) Scale, and the Eczema Area and Severity Index (EASI) [21-25]. We also took into account the investigator's assessment of severity. All scales had been previously translated into Portuguese and validated for the Brazilian population. Our Overall Severity AD Index was determined as the highest degree of severity among all available assessments for each patient during the study. Severity assessed with each scale was determined at different time points.

Regarding disease management and treatment, we assessed the number of hospitalizations due to $\mathrm{AD}$, the mean length of stay per patient, the mean follow-up time, and the number of medical appointments per patient. We also collected information on the $\mathrm{AD}$ treatments prescribed and other adjuvant therapies for AD. Patients were also characterized according to their immune response profile [26], considering as elevated IgE levels $>100 \mathrm{IU} / \mathrm{mL}$ (measured using nephelometry or fluoroenzymatic assay) and peripheral blood eosinophil counts $>5 \%$ [13] during the previous 36 months.

\section{Sample Size}

Given the descriptive nature of this study, the sample size was calculated to ensure a robust and representative population. Assuming losses of approximately $15 \%$, a total of 200 patients were required to achieve 171 eligible patients. This estimation was based on an expected rate of hospitalizations of $56 \%$ [13], considering a $95 \% \mathrm{CI}$ and a margin of error of less than $7.5 \%$. The sample size was computed using nQuery Advisor, version 7.0.

\section{Statistical Analysis}

Multiple answers were allowed for most of the collected data, implying that more than 1 option could be reported for the same patient. For descriptive options, such as "Other", terms were analyzed using a standard approach, according to the Medical Dictionary for Regulatory Activities. All results were summarized as number (nonmissing data), mean, standard deviation, minimum and maximum values for continuous variables, and counts and percentages for categorical variables. All analyses were conducted using SAS, version 9.4.

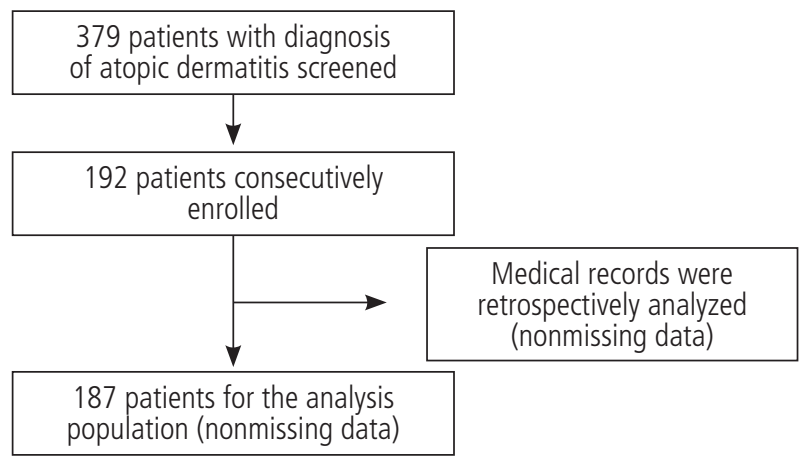

Figure 1. Flow chart of the study population.

\section{Results}

\section{Study Participants}

Of the 192 patients enrolled, 5 (2.6\%) were excluded from the analysis due to missing data, with the analysis population comprising 187 patients (Figure 1).

Table 2. Demographic Data, Family and Personal History of Atopic Dermatitis (AD), and Asthma or Allergic Disease of the Study Patients ${ }^{\mathrm{a}}$

\begin{tabular}{|c|c|}
\hline Characteristics of AD Patients & $\mathrm{n}=187$ \\
\hline \multicolumn{2}{|l|}{ Demographic data } \\
\hline \multicolumn{2}{|l|}{ Age (years) $)^{b}$} \\
\hline Mean (SD $[95 \% \mathrm{CI}])$ age at first visit & $\begin{array}{c}24.7 \\
(13.4[22.8-26.6])\end{array}$ \\
\hline Mean (SD $[95 \% \mathrm{CI}])$ age at last visit & $\begin{array}{c}33.7 \\
(13.0[31.9-35.6])\end{array}$ \\
\hline \multicolumn{2}{|l|}{ Sex, No. $(\%)$} \\
\hline Male & $82(43.9 \%)$ \\
\hline Female & $105(56.1 \%)$ \\
\hline \multicolumn{2}{|l|}{ Ethnicity, No. (\%) } \\
\hline White & $134(71.7 \%)$ \\
\hline Mixed & $21(11.2 \%)$ \\
\hline Black & $12(6.4 \%)$ \\
\hline Asian & $1(0.5 \%)$ \\
\hline Missing data & $19(10.2 \%)$ \\
\hline \multicolumn{2}{|l|}{ Family and personal history of $A D$} \\
\hline \multicolumn{2}{|l|}{ Onset of AD } \\
\hline Age (years), mean (SD [95\%CI]) & $\begin{array}{c}13.1 \\
(13.6[10.9-15.3])\end{array}$ \\
\hline Median age (range), y & $7.0(0.5-59)$ \\
\hline Missing data & $45(24.1 \%)$ \\
\hline \multicolumn{2}{|c|}{ Family history of $\mathrm{AD}$, asthma or allergic disease } \\
\hline \multicolumn{2}{|l|}{ Patients with family history of any } \\
\hline allergic disease & $70(37.4 \%)$ \\
\hline Allergic rhinitis & $44 / 70(62.8 \%)$ \\
\hline Asthma & $36 / 70(51.4 \%)$ \\
\hline Atopic dermatitis & $18 / 70(25.7 \%)$ \\
\hline Other ${ }^{\mathrm{c}}$ & $5 / 70(7.1 \%)$ \\
\hline No family history & $5(2.7 \%)$ \\
\hline Missing data & $112(59.9 \%)$ \\
\hline \multicolumn{2}{|l|}{ Personal history of asthma or allergic disease } \\
\hline \multicolumn{2}{|l|}{ Patients with personal history of asthma } \\
\hline Allergic rhinitis & $125 / 150(83.3 \%)$ \\
\hline Asthma & $96 / 150(64.0 \%)$ \\
\hline Conjunctivitis & $13 / 150(8.6 \%)$ \\
\hline Food allergy & $7 / 150(4.6 \%)$ \\
\hline Other $^{\mathrm{d}}$ & $22 / 150(14.6 \%)$ \\
\hline No personal history & $2(1.1 \%)$ \\
\hline Missing data & $35(18.7 \%)$ \\
\hline
\end{tabular}

Abbreviation: $A D$, atopic dermatitis.

a Multiple answers were allowed during the data collection. Missing data or unknown responses were not considered for calculation of the percentage (unless otherwise specified).

bIf " $<1 "$ ", then age was set as " $0.5 "$.

'Other: Drug hypersensitivity (1.1\%), anxiety disorder (0.5\%), and contact dermatitis $(0.5 \%)$.

dOther: Contact dermatitis (2.7\%), drug hypersensitivity (2.1\%), and angioedema (1.6\%). 
Table 3. Comorbidities and Laboratory Changes in the Study Population, at the First Visit and During the Last 36 Months $^{\mathrm{a}}$

\begin{tabular}{lcc}
$\begin{array}{l}\text { Comorbidities and } \\
\text { Laboratory Changes }\end{array}$ & $\begin{array}{c}\text { First Study Visit } \\
\mathrm{n}=187 \text { Patients }\end{array}$ \\
\hline $\begin{array}{l}\text { Any comorbidity and/or } \\
\text { laboratory change }\end{array}$ & $40(21.4 \%)$ & $46(24.6 \%)$ \\
$\begin{array}{l}\text { Hypertension } \\
\text { Diabetes mellitus }\end{array}$ & $10(5.3 \%)$ & $19(10.2 \%)$ \\
$\begin{array}{l}\text { Mood disorders (depression, } \\
\text { anxiety, suicidal ideation) }\end{array}$ & $7(2.1 \%)$ & $9(4.8 \%)$ \\
Change in renal function & $1(0.5 \%)$ & $1(0.5 \%)$ \\
Change in hepatic function & $0(0.0 \%)$ & $1(0.5 \%)$ \\
Other & $37(19.8 \%)$ & $36(19.3 \%)$ \\
\hline
\end{tabular}

a Multiple answers were allowed during the data collection. Missing data or unknown responses were not considered for calculation of the percentage (unless otherwise specified).

${ }^{b}$ Other comorbidities: at first visit, allergic rhinitis (4.3\%), asthma $(2.1 \%)$, contact dermatitis (2.1\%); at last visit, contact dermatitis $(4.3 \%)$, blood cortisol decrease (1.1\%), keratoconus (1.1\%), neurodermatitis (1.1\%), and primary adrenal insufficiency (1.1\%).

Among this analysis population, 105 (56.1\%) were women and 134 (71.7\%) were White. The mean (SD) age at enrollment was 24.7 (13.4) years (range, 18-69.5 years). Patient demographics, as well as family and personal history of $\mathrm{AD}$, asthma, and allergic diseases are presented in Table 2. Four women $(3.8 \%)$ were pregnant at enrollment or during the study. The mean age at onset of AD was 13.1 years, and the condition started between the ages of 1 and 7 years in 57 patients $(38.8 \%)$.

Seventy patients $(37.4 \%)$ had a family history of allergic rhinitis $(62.8 \% ; 44 / 70)$, asthma $(51.4 \% ; 36 / 70)$, and atopic dermatitis $(25.7 \% ; 18 / 70)$. Regarding the personal history, 150 patients $(80.2 \%)$ had mainly allergic rhinitis $(83.3 \% ; 125 / 150)$, asthma $(64.0 \% ; 96 / 150)$, conjunctivitis $(8.6 \% ; 13 / 150)$, and food allergy $(4.6 \% ; 7 / 150)$. The proportion of patients who had at least 1 comorbidity and/or laboratory changes increased by $3.2 \%$ between the first and last study visits (Table 3 ).

\section{Clinical Characterization of $A D$}

Data on the distribution and morphology of skin lesions were collected retrospectively from medical records at the first and last visits, within 36 months of follow-up. All patients $(100 \%)$ had at least 1 type of skin lesion at the first visit, compared with 181 patients $(96.8 \%)$ at the last visit (note that each patient could present more than 1 condition). Most skin lesions were nonflexural and flexural (Table 4). Nonflexural lesions were located mostly on the legs, trunk, and arms. Among affected patients, 17 (9.1\%) (first visit) and 15 (8.0\%) (last visit) also had lesions on extensor surfaces that were equally distributed between the elbows and knees. Flexural lesions were distributed mainly on the popliteal, antecubital, and neck areas.

Regarding morphology, most lesions were typical, with a lichenified/exudative eczematous pattern (Figure 2).
AD manifestations (any kind) were reported by 162 patients $(86.6 \%)$ at the first visit and by $149(79.7 \%)$ at the last visit. The main manifestations, including pruritus, erythema, and dry skin, are described in Figure 3.

To determine the severity of AD, a total of 941 assessments were performed, including 1 of the 5 scoring options mentioned

Table 4. Distribution of Skin Lesions on the Body at the First Visit and During the Last 36 Months $^{\mathrm{a}}$

\begin{tabular}{lcc} 
Location of Skin Lesions & $\begin{array}{c}\text { First Study } \\
\text { Visit }\end{array}$ & $\begin{array}{c}\text { Last } \\
36 \text { Months }\end{array}$ \\
& \multicolumn{2}{c}{ No. (\%) } \\
& \multicolumn{2}{c}{} \\
Patients with some & $187(100 \%)$ & $181(96.8 \%)$ \\
kind of lesion & $44(23.5 \%)$ & $53(28.3 \%)$ \\
Missing data & $92(49.2 \%)$ & $70(37.4 \%)$ \\
Flexural & $64(34.2 \%)$ & $50(26.7 \%)$ \\
Popliteal & $65(34.8 \%)$ & $42(22.5 \%)$ \\
Antecubital & $38(20.3 \%)$ & $31(16.6 \%)$ \\
Neck & $12(6.4 \%)$ & $19(10.2 \%)$ \\
Ankles & $13(7.0 \%)$ & $14(7.5 \%)$ \\
Axillae & $13(7.0 \%)$ & $13(7.0 \%)$ \\
Writs & $17(9.1 \%)$ & $15(8.0 \%)$ \\
Extensors & $114(61.0 \%)$ & $101(54.0 \%)$ \\
Nonflexural & $65(34.8 \%)$ & $53(28.3 \%)$ \\
Legs & $55(29.4 \%)$ & $45(24.1 \%)$ \\
Trunk & $55(29.4 \%)$ & $41(21.9 \%)$ \\
Arms & $45(24.1 \%)$ & $36(19.3 \%)$ \\
Face & $19(10.2 \%)$ & $16(8.6 \%)$ \\
Eyelids & $10(5.3 \%)$ & $22(11.8 \%)$ \\
Hands & $13(7.0 \%)$ & $14(7.5 \%)$ \\
Feet & $13(7.0 \%)$ & $6(3.2 \%)$ \\
Ears & $7(3.7 \%)$ & $9(4.8 \%)$ \\
Lips & $5(2.7 \%)$ & $8(4.3 \%)$ \\
Scalp & $7(3.7 \%)$ & $6(3.2 \%)$ \\
Nipples & $5(2.7 \%)$ & $6(3.2 \%)$ \\
Retroauricular area & $2(1.1 \%)$ & $3(1.6 \%)$ \\
Anogenital & $19(10.2 \%)$ & $14(7.5 \%)$ \\
Others & & \\
\hline & &
\end{tabular}

aultiple answers were allowed during data collection. Missing data or unknown responses were not considered for calculation of the percentage (unless otherwise specified).

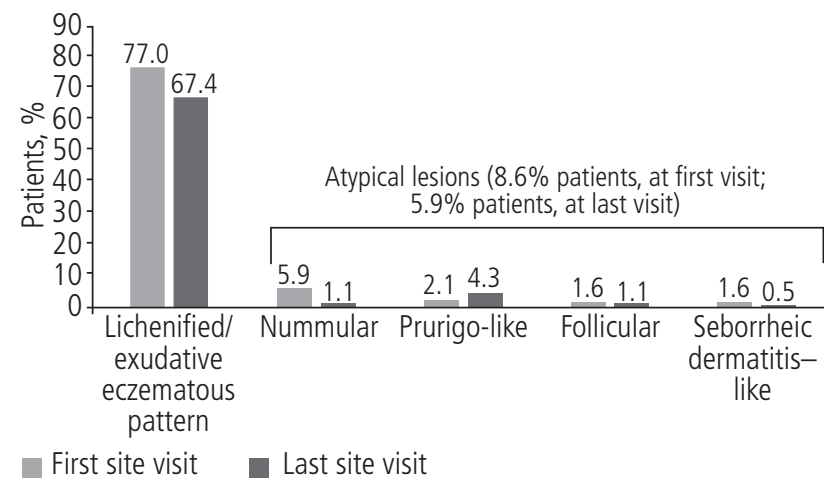

Figure 2. Clinical characteristics of atopic dermatitis lesions in ADAPT patients. 


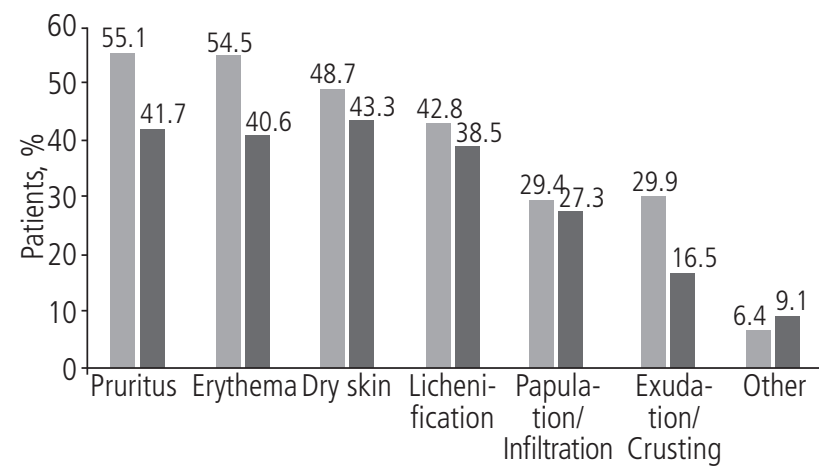

First site visit

Last site visit

Figure 3. Manifestations of atopic dermatitis in the study population, considering the first and the last visits of the study period (percentage of patients). Percentages were calculated with $N_{\text {total }}=187$ as the denominator. ("Other" includes skin exfoliation, skin hyperpigmentation, and excoriation.

in the Methods section. According to the Overall AD Severity Index, defined as the worst severity obtained among the scores applied to each patient, 27 patients $(16.9 \%)$ were classified as mild, $28(17.5 \%)$ as moderate, and $105(65.6 \%)$ as severe. Among the subpopulation using immunosuppressants, $48.5 \%$ of patients were classified as severe. The investigator classification available in medical records was used to assess severity in 137 patients (73.3\%) (799 measurements) and the SCORAD was used in 98 patients (52.4\%) (280 measurements). IGA and EASI scores were available for 31 patients $(16.6 \%)$ and 32 patients $(17.1 \%)$, respectively. Nonetheless, IGA (total measurements, 148) was used more frequently than EASI (total measurements, 48). AD severity scores, defined as the worst score during the study period, are presented in Table 5 .

\section{Disease Management and Treatment}

Patients were followed for approximately 9 years. Sixteen patients $(8.6 \%)$ were hospitalized at least once because of AD, and 2 of these were hospitalized more than once (Table 6).

Patients received both pharmacological and nonpharmacological treatments for $\mathrm{AD}$, in addition to adjuvant therapies for complications of the disease. Each patient could receive more than 1 treatment. Topical treatments were prescribed for 183 patients $(97.9 \%)$ and systemic treatments for $171(91.4 \%)$; 183 patients were simultaneously taking more than 1 treatment during the course of the study. Immunobiological therapies were prescribed to $17(9.1 \%)$ patients, including $5.9 \%$ of patients receiving anti-IgE therapy with omalizumab, and phototherapy was indicated in 8 patients $(4.3 \%)$. Most patients received systemic and/or topical pharmacological therapy (Figure 4). Topical treatments were mainly corticosteroids $(88.2 \%, 165 / 187)$ and emollients $(85.6 \%, 160 / 187)$, while the most frequently used systemic disease-modifying treatment was oral corticosteroids $(32.6 \%$, $61 / 187)$. Seventy patients took systemic corticosteroids (oral corticosteroids, 61; injectable corticosteroids, 4; and a combined formulation of corticosteroid with antihistamine, 5).
Table 5. Scores of Severity of Atopic Dermatitis (AD) During the Entire Study

\begin{tabular}{|c|c|}
\hline Severity Scores & $\mathrm{n}=187$ Patients \\
\hline $\begin{array}{l}\text { Patients with at least one } \\
\text { recorded evaluation of AD severity; } \\
\text { No of measurements }\end{array}$ & $160(85.6 \%) ; 941$ \\
\hline $\begin{array}{l}\text { Patients with any data on need of } \\
\text { immunosuppressant therapy }\end{array}$ & $165(88.2 \%)$ \\
\hline $\begin{array}{l}\text { Severity score, } \mathrm{n} / \mathrm{N} 1(\%)^{\mathrm{a}} \\
\text { No assumption of severity score } \\
\text { Severe }\end{array}$ & $\begin{array}{l}85 / 165(51.5 \%) \\
80 / 165(48.5 \%)\end{array}$ \\
\hline $\begin{array}{l}\text { Investigator classification available } \\
\text { in the medical records }\end{array}$ & $137(73.3 \%)$ \\
\hline $\begin{array}{l}\text { Severity score, } \mathrm{n} / \mathrm{N} 1(\%)^{\mathrm{a}} \\
\text { Mild } \\
\text { Moderate } \\
\text { Severe }\end{array}$ & $\begin{array}{l}30 / 137(21.9 \%) \\
35 / 137(25.5 \%) \\
72 / 137(52.6 \%)\end{array}$ \\
\hline SCORAD $^{\mathrm{b}}$ & $98(52.4 \%)$ \\
\hline $\begin{array}{l}\text { Severity score, } \mathrm{n} / \mathrm{N} 1(\%)^{\mathrm{a}} \\
\quad \text { Mild }(<25) \\
\text { Moderate }(25-50) \\
\text { Severe }(>50)\end{array}$ & $\begin{array}{l}13 / 98(13.3 \%) \\
38 / 98(38.8 \%) \\
47 / 98(48.0 \%)\end{array}$ \\
\hline IGA $^{\mathrm{c}}$ & $31(16.6 \%)$ \\
\hline $\begin{array}{l}\text { Severity score, } \mathrm{n} / \mathrm{N} 1(\%)^{\mathrm{a}} \\
\text { Clear (no inflammatory signs of AD) } \\
\text { Almost clear (just perceptible erythema, } \\
\text { and just perceptible papulation/infiltration) } \\
\text { Mild (mild erythema and } \\
\text { papulation/infiltration) } \\
\text { Moderate (moderate erythema and } \\
\text { papulation/infiltration) } \\
\text { Severe (severe erythema and } \\
\text { papulation/infiltration) } \\
\text { Very severe (very severe erythema } \\
\text { and papulation/infiltration) }\end{array}$ & $\begin{array}{r}0 / 31(0.0 \%) \\
2 / 31(6.5 \%) \\
4 / 31(12.9 \%) \\
9 / 31(29.0 \%) \\
7 / 31(22.6 \%) \\
9 / 31(29.0 \%)\end{array}$ \\
\hline $\mathrm{EASI}^{\mathrm{d}}$ & $32(17.1 \%)$ \\
\hline $\begin{array}{l}\text { Severity score, } \mathrm{n} / \mathrm{N} 1(\%) \mathrm{a} \\
\text { Clear }(0) \\
\text { Almost clear }(0.1-1.0) \\
\text { Mild }(1.1-7.0) \\
\text { Moderate }(7.1-21.0) \\
\text { Severe }(21.1-50.0) \\
\text { Very severe }(50.1-72.0)\end{array}$ & $\begin{array}{c}0 / 32(0.0 \%) \\
0 / 32(0.0 \%) \\
8 / 32(25.0 \%) \\
13 / 32(40.6 \%) \\
8 / 32(25.0 \%) \\
3 / 32(9.4 \%)\end{array}$ \\
\hline
\end{tabular}

${ }^{a} A D$ severity defined as worst score during the entire study period, based on the total number of patients who completed the score. bSCORAD, Scoring Atopic Dermatitis. SCORAD values ranged from 0 to 96 in the present study.

ฯGA, Investigator Global Assessment scale.

'EASI, Eczema Area and Severity Index. EASI values ranged from 3 to 57 in the present study.

Of the 66 patients who took oral corticosteroids/oral corticosteroid combined with antihistamine in the same formulation, data on treatment duration were available for 51 patients. Duration of oral corticosteroid treatment varied widely, from 3 to 1765 days, with a mean duration of 65.4 (208.3) days and a median duration of 15 (6.7-31) per course. 
Table 6. Management of AD Including Medical Appointments and Hospitalizations During the Study

\begin{tabular}{|c|c|}
\hline Management of AD & $\mathrm{n}=187$ Patients \\
\hline Mean (SD) total follow-up period, mo & $108.4(64.9)$ \\
\hline $\begin{array}{l}\text { Mean (SD [range]) number of medical } \\
\text { appointments }\end{array}$ & $10.1(5.6[2-28])$ \\
\hline $\begin{array}{l}\text { Mean (SD [range]) time between medical } \\
\text { appointments, mo }\end{array}$ & $6.7(6.7[1.3-36])$ \\
\hline Patients with at least 1 hospitalization & $16(8.6 \%)$ \\
\hline $\begin{array}{l}\text { Mean (SD [range]) duration of hospitalization } \\
\text { per patient, } d\end{array}$ & n $5.8(6.3[1-23])$ \\
\hline
\end{tabular}

A

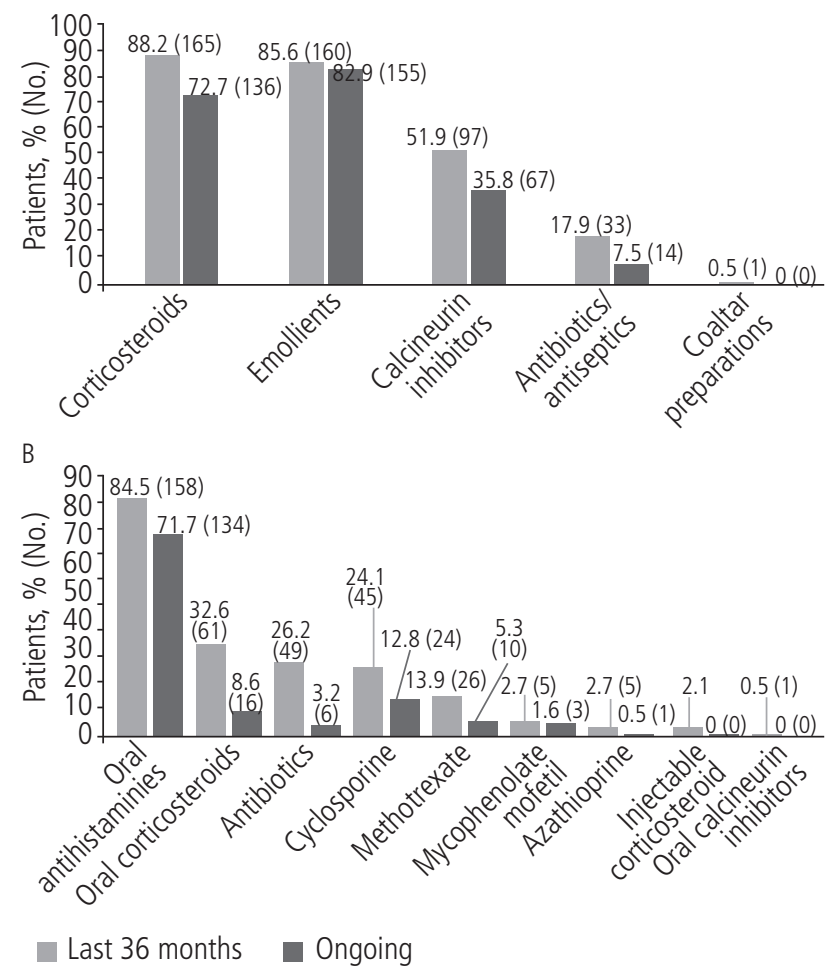

Figure 4. Pharmacological treatment for atopic dermatitis (A, Topical; $B$ Systemic) administered over the last 36 months and ongoing prescriptions at the last study visit. Percentages were calculated with $\mathrm{N}_{\text {total }}=187$ as the denominator.

Oral anti- $\mathrm{H}_{1}$ antihistamines were also used by most patients $(84.5 \%, 158 / 187)$ to control AD symptoms.

Regarding nonpharmacological treatment, 22 (11.8\%) patients received other therapies or psychological support, including psychotherapy $(95.4 \%, 21 / 22)$, participation in AD support groups $(18.1 \%, 4 / 22)$, and psychiatric monitoring $(4.5 \%, 1 / 22)$. Additionally, $125(66.8 \%)$ patients were prescribed adjuvant therapy for complications associated with $\mathrm{AD}$ (Figure 5).

As presented in Figure 6, 148 patients (79.1\%) discontinued or switched AD treatment, mainly due to disease remission
$(46.5 \%, 87 / 187)$, poor effectiveness $(33.7 \%, 63 / 187)$, or lack of adherence $(12.9 \%, 24 / 187)$. Other reasons $(13.9 \%, 26 / 187)$ included treatment time $(5.3 \%, 10 / 187)$, dose reduction $(2.7 \%, 5 / 187)$, and drug shortage $(1.6 \%, 3 / 187)$. It should be highlighted that patients could have 1 or more reasons to stop or change pharmacological treatment of AD.

Not all patients stopped pharmacological therapies for AD during the study. For instance, 144 patients (77.0\%) maintained topical corticosteroids, with a mean duration of 41.3 months per patient, and $77(41.2 \%)$ were taking topical calcineurin inhibitors for a mean duration of 33.2 months per patient. As for systemic therapies, 45 participants $(24.1 \%)$ were treated with cyclosporine for an average of 13.2 months per patient and, lastly, 25 participants (13.4\%) were treated with methotrexate for an average of 7.9 months per patient.

\section{Immune Pathway of AD Patients}

Laboratory findings of 89 patients with at least 1 registered measure were assessed to define the immune profile of $\mathrm{AD}$ patients (Table 7). Of those, 84 (94.4\%) presented IgE levels $>100 \mathrm{IU} / \mathrm{mL}$, while $76(64.4 \%)$ had eosinophil counts $>5 \%$.

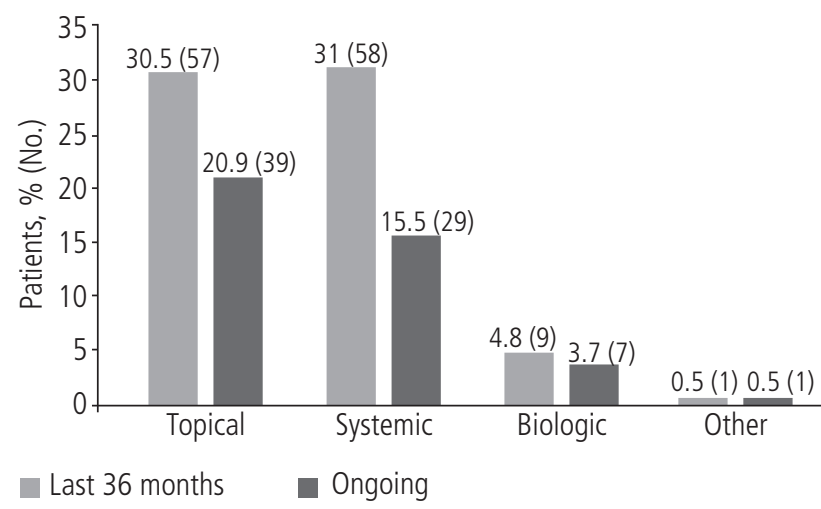

Figure 5. Adjuvant treatment for complications of atopic dermatitis administered over the last 36 months and ongoing prescriptions at the last study visit. Percentages were calculated with $N_{\text {total }}=187$ as the denominator.

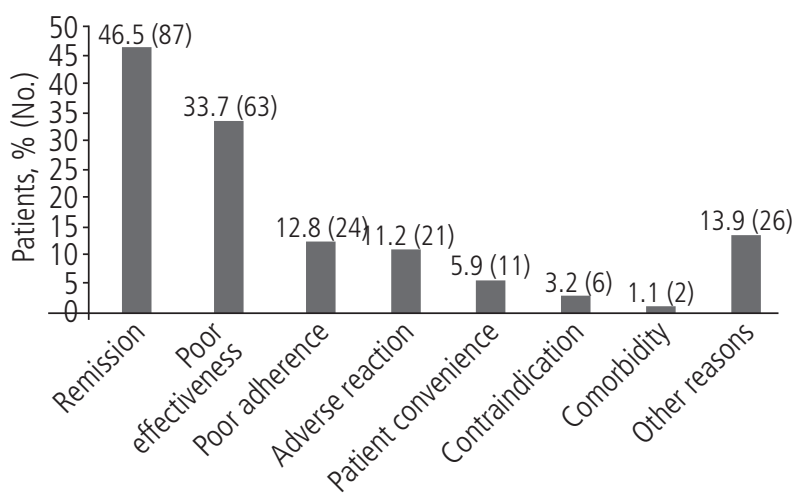

Figure 6. Reasons for stopping or changing pharmacological treatment for atopic dermatitis. Percentages were calculated with $N_{\text {total }}=187$ as the denominator. 
Table 7. Analyses of Total IgE and Peripheral Blood Eosinophils, in the Last 36 Months and at the Most Recent Study Visit

\begin{tabular}{|c|c|c|}
\hline Immunological Parameters & $\begin{array}{l}\text { Last } 36 \text { Months }^{\mathrm{a}} \\
\mathrm{n}=187 \text { Patients }\end{array}$ & $\begin{array}{l}\text { Last Measurement } \\
\mathrm{n}=187 \text { Patients }\end{array}$ \\
\hline \multicolumn{3}{|l|}{ Serum total $\mathrm{IgE}, \mathrm{IU} / \mathrm{mL}$} \\
\hline Any measurement (Patients; No. [\%]) & $89(47.6 \%)$ & \\
\hline $\operatorname{IgE}>100 \mathrm{IU} / \mathrm{mL},(\mathrm{n} / \mathrm{N} 1)^{\mathrm{c}}$ & $84 / 89(94.4 \%)$ & \\
\hline Mean IgE $(95 \% \mathrm{CI})$ & $13316.3(8232.4-18400.3)$ & $10688.9(6006.9-15370.9)$ \\
\hline Median (range) & $5000.0(2-184000)$ & $3133.0(2-184000)$ \\
\hline \multicolumn{3}{|l|}{ Eosinophil counts $(\%)$} \\
\hline Any measurement (Patients; No. [\%]) & & $118(63.1 \%)$ \\
\hline Blood eosinophilia $>5 \%$ & $76(64.4 \%)$ & $66(55.9 \%)$ \\
\hline Mean value $(95 \% \mathrm{CI})$ & $9.6(8.1-11)$ & $7.6(6.3-8.9)$ \\
\hline Median (range) & $7.9(0-47.1)$ & $5.4(0-45.6)$ \\
\hline
\end{tabular}

aHighest value observed.

bValue collected during the most recent study visit.

$\mathrm{n} / \mathrm{N} 1$ = number of patients who met the laboratory criterion/ number of patients assessed.

Considering the last registered value, 66 patients $(55.9 \%)$ showed increased levels of eosinophils $(>5 \%)$. The results suggested that most patients presented characteristics indicating type 2 immune pathway activation [26,27].

\section{Discussion}

Adults with $\mathrm{AD}$ frequently experience intense flare-ups due to lack of disease control [10]. AD is often chronic, with a low decrease in prevalence (1\%) after the age of 12 [28]. Several studies report a high patient burden and a relevant impact on mental health, work absenteeism, and daily activities [29-31], similar to psoriasis [32]. Effective treatments lead to lower discontinuation rates and fewer adverse effects, while their absence represents an unmet need in patients with $\mathrm{AD}$, especially those with moderate-to-severe disease. Hence, optimization of both patient journey and disease course must become a priority for adult patients.

The ADAPT study sought to define the characteristics of adults with AD in terms of demographic and clinical features, disease management, and laboratory findings. Most patients were female and White, with a mean age of 24.7 years. These characteristics were similar in patients from Europe, the USA, and Canada, where the prevalence of AD was higher in adults aged 25 to 44 years and in females [1]. Around $80 \%$ of the patients had a personal history of asthma and/or allergic rhinitis, although only $37.4 \%$ reported a family history of $\mathrm{AD}$, asthma, or allergic disease. These characteristics were comparable to those of other populations, where most adults had an associated respiratory disease (asthma, rhinitis, or both) [13,33]. Approximately $21 \%$ of patients had at least 1 comorbidity, mainly hypertension and/or changes in laboratory values. Our results are consistent with those of an Italian population-based study, in which hypertension was also frequent (7.1\%) [33], and with a Spanish study that showed high associated morbidity, especially hypertension, in adults with severe $\mathrm{AD}(37.6 \%)$ [3].
The frequency of hypertension in our study (10.2\%) was lower than the prevalence reported in adults from the general population in Brazil (30.5\%-52.5\%) [34,35]. However, adult patients with $\mathrm{AD}$ in the present study were younger (mean age, 24.7 years) than those included in studies of hypertension in the general Brazilian population (median age of 41 and mean age of 52 years) [34,35]. A systematic review of 40 studies comprising over 120000 individuals (mostly aged $\geq 18$ years) estimated the prevalence of hypertension in Brazil to be $28.7 \%(95 \% \mathrm{CI}, 26.2-31.4)$ [36]. In the French population, common comorbidities in $\mathrm{AD}$ patients included atopic, allergic, autoimmune, and cardiovascular diseases [14].

In our study population, the skin lesions presented mainly a lichenified/exudative eczematous pattern. Such lesions were described as a distinct form in adults with $\mathrm{AD}$, although adults may characteristically present heterogeneous mixed forms of pediatric $\mathrm{AD}$ [2]. In an Italian cohort, flexural lesions (upper limbs) were more frequent (47.8\%), followed by lesions on the eyelid and periocular area, with an erythematous-desquamative pattern (74.3\%) [33]. The distribution of nonflexural rash and atypical morphology are also common in adults, for example, on the head and neck or extensor surfaces of the limbs and trunk [2,14,31]. In our study, flexural rash was mostly distributed on the popliteal, antecubital, and neck areas, while nonflexural rash was generally present on the legs, arms, and trunk. Furthermore, clinical features may vary according to age, age of disease onset, and characteristics of acute/chronic AD [14]. Patients with persistent AD (pre-adult onset) show increased disease severity, intensity of pruritus, and comorbidities (eg, hypertension), compared with adult-onset $\mathrm{AD}$ [33]. In addition, the location of skin lesions might vary according to age of onset [37]. Patients in the ADAPT study mainly had pre-adult onset $\mathrm{AD}$, with a mean age of onset of 13.1 years, which is comparable to data reported elsewhere [30,37].

Our findings are in line with those of previous studies on the manifestations of $\mathrm{AD}$, since pruritus, erythema, and dry skin were reported by most patients $[1,30,38]$. A slight 
variance was found between patients who reported pruritus (55.1\% at the first visit; $41.7 \%$ at the last visit) and dry skin (48.7\% at the first visit; $43.3 \%$ at the last visit). This difference might reflect a variation in patient perception about how such major symptoms impact their daily activities [30]. Our results also demonstrated that $83.1 \%$ had moderate-to-severe disease, as assessed using 5 different scores. Of these, only the SCORAD index includes 2 patient-reported outcomes, which are related to pruritus and impact on sleep [30]. This high proportion of patients with moderate-to-severe disease should be interpreted with caution, as the study population included patients followed in tertiary care, who present a more severe disease form. Differences in the severity of AD were observed in other countries, with France, Italy, Japan, and Spain reporting higher proportions of mild AD, while Canada, Germany, and the USA reported higher scores of severe AD [1]. Additionally, in a multicenter study from Spain, $41.6 \%$ of the adults diagnosed with moderate-to-severe $\mathrm{AD}$ had poor disease control [10].

Regarding disease management, it should be highlighted that after 9 years of follow-up, $16(8.6 \%)$ patients had been hospitalized at least once owing to AD. Compared with another study of Brazilian patients, where $56 \%$ had been hospitalized at least once since diagnosis [13], our study reported a lower number of hospitalizations. Nonetheless, an increased use of health care resources has been outlined in other populations with AD [29,39].

In Brazil, patients with severe $\mathrm{AD}$ need more effective therapies and well-established treatment goals to improve their care. In the ADAPT study, we characterized the treatment patterns of Brazilian patients with $\mathrm{AD}$ and found that, overall, most patients received systemic and/or topical pharmacological therapy, followed by immunobiological treatments (eg, omalizumab) and phototherapy. In other studies assessing therapeutic trends in $\mathrm{AD}$, patients frequently used topical pharmacological treatments, such as corticosteroids, calcineurin inhibitors, and antihistamines [10,33,39]. A relevant percentage of ADAPT patients (36.2\%) received oral corticosteroids, as reported in other real-life studies $[13,30,33,39]$. Despite this evidence, oral corticosteroids are recommended in treatment guidelines only for a short period to control severe exacerbations $[19,20]$. Oral corticosteroids can be prescribed through a family physician or taken as self-medication, which is possible in Brazil [40]. A recent global survey found that AD was generally diagnosed by dermatologists, but also by a family physician or, eventually, by the patient him/herself [1]. Only $48.2 \%$ of patients who self-diagnosed with $\mathrm{AD}$ had their diagnosis confirmed by a physician [1]. In our study, oral antihistamines, frequently administered to manage pruritus [19], were the most used systemic treatment $(84.5 \%)$.

According to guidelines, systemic treatments, including corticosteroids and cyclosporine, have limited indications for $\mathrm{AD}$ and may not be suitable for long-term use, potentially due to serious adverse effects [20]. In the ADAPT study, adverse reaction was the reason for stopping or changing any pharmacological treatment for AD in $11.2 \%$ of patients. Most importantly, patients discontinued or switched AD treatment due to poor effectiveness $(33.7 \%)$ and lack of adherence $(12.8 \%)$. Still, almost half of the patients stopped treatment due to remission. Comparison of the duration of topical and systemic treatments revealed that $77.0 \%$ of patients maintained treatment with topical corticosteroids, while only $24.1 \%$ maintained treatment with cyclosporine. Besides pharmacological treatment, approximately $12 \%$ of patients were receiving psychological support, thus highlighting the burden of this disease.

Finally, considering that IgE and eosinophil cut-offs were $>100 \mathrm{IU} / \mathrm{mL}$ and $>5 \%$, respectively, most patients presented characteristics of type 2 inflammation [27]. Extrinsic AD is characterized by a predominant type 2 immune response, defined by a $\mathrm{T}_{\mathrm{H}} 2$ - and ILC-2-based pathophysiology, as well as $\operatorname{IgE}$-mediated sensitization $[41,42]$. Eosinophilia is also present in areas of skin inflammation, resulting from secretion of cytokines and other proinflammatory mediators. Our results suggest extrinsic-type $\mathrm{AD}$, which is characterized by elevated IgE levels and high eosinophil blood counts $[3,13]$. A positive correlation has been reported between disease severity and blood eosinophil counts and high serum IgE levels [13]. Therefore, controlling this immune response is of the utmost importance for preventing exacerbations, particularly in patients with moderate-to-severe AD.

Despite its epidemiologic significance, this study presents limitations inherent to its design and retrospective nature. Since data were collected from different types of medical charts and participating sites, data were missing in some cases, and inconsistencies were found in the information collected. In addition, we did not evaluate the efficacy of treatment modalities, or whether patients were also taking other medications for respiratory comorbidities. Based on this registry study, future prospective studies could incorporate quality of life measurements and apply patient-reported outcomes to assess patient perspectives on disease burden and use of health care resources.

\section{Conclusion}

When managing adult patients with $\mathrm{AD}$, we need to consider several issues, such as substantial use of systemic corticosteroids, presence of multiple comorbidities, and need for psychological and mental health support. New investigations should focus on patients with moderate-tosevere $\mathrm{AD}$, for whom more effective and targeted treatments may improve disease control and quality of life and reduce healthcare costs.

\section{Acknowledgments}

The authors would like to thank all coinvestigators involved in the recruitment of patients and data collection for the ADAPT study, as follows and in no specific order: Janaina Michelle Lima Melo, MD, PhD and Julianne Alves Machado, MD from the Clinical Hospital of Ribeirão Preto Medical School; Carolina Bensi Lucia, MD from the Department of Dermatology, Faculdade de Medicina ABC; Raquel Leão Orfali, MD, PhD, Mariana Colombini Zaniboni MD, MSc, and Nelise Hans, MD from the Department of Dermatology, Faculdade de Medicina USP-SP; Maria Elisa Bertocco 
Andrade, MD and Maria do Rosário Vidigal, MD from Complexo Hospitalar Padre Bento; José Alexandre Sittart, $\mathrm{MD}, \mathrm{PhD}$ from Hospital do Servidor Público Estadual de São Paulo; Solange Rodrigues Valle, MD, PhD, Melanie Hurel, $\mathrm{PhD}$ student, and Luciana Souto, MSc student from HUCFF/ UFRJ; Patrícia Salles Cunha, MD from Hospital das Clínicas da Faculdade de Medicina da USP (FMUSP); Anber Tanaka, MD, PhD from Faculdade Evangélica do Paraná (HUEC / FEPAR). In addition, the authors wish to thank Suely Goldflus, MD from Sanofi Genzyme Brasil and Ana Truzzi and Priscila Basso from Sanofi Brasil for their assistance in the study design and statistical analysis and for operational support. Finally, the authors thank Catarina Oliveira Silva from CTI, Clinical Trials $\&$ Consulting Services for the editorial support provided for this manuscript.

\section{Funding}

This study was financially supported by Sanofi.

\section{Conflicts of Interest}

L Karla Arruda: Investigator for the ADAPT Study (Sanofi); Speaker for Sanofi, Novartis, Shire, and Chiesi at medical conferences.

Ariana C Yang: Investigator for the ADAPT Study (Sanofi); Speaker for Sanofi and Danone.

Valéria Aoki: Investigator for the ADAPT Study (Sanofi).

Roberta FJ Criado: Investigator for the ADAPT Study (Sanofi); Speaker for Novartis, and GlaxoSmithKline.

Mario C Pires: Investigator for the ADAPT Study (Sanofi) and other clinical studies from Novartis and Libbs; Speaker for Sanofi, Farmoquímica, and Galderma; Consultant for Sanofi.

Omar Lupi: Investigator for ADAPT Study (Sanofi) and other clinical studies from Pfizer; speaker for USK, Aché, Sanofi, Galderma, Leo Pharma; participation in Advisory Board for Sanofi.

Lincoln HZ Fabricio: Investigator for ADAPT Study (Sanofi); speaker for Abbott/AbbVie, Bayer, Bioderma, Biolab, Boticário, Galderma, Hypermarcas, Isdin, Janssen, La RochePosay, LeoPharma, Pfizer, Stiefel, and GlaxoSmithKline; travel support for scientific events from Abbott/AbbVie, Bayer, Bioderma, Galderma, Isdin, Janssen, La Roche-Posay, Leo Pharma, Pfizer, Merck Sharp \& Dohme, and Novartis; participation in Advisory Boards for Bayer, Janssen, La RochePosay, Leo Pharma, and Merck Sharp \& Dohme.

Daniel Richman is Global Medical Director of Sanofi Genzyme, Cambridge, MA, United States.

Susanna Silvi is a collaborator for Medical Affairs of Sanofi Genzyme, Brazil.

\section{References}

1. Barbarot S, Auziere S, Gadkari A, Girolomoni G, Puig L, Simpson EL, et al. Epidemiology of atopic dermatitis in adults: Results from an international survey. Allergy. 2018;73:1284-93.

2. Silvestre Salvador J, Romero-Pérez D, Encabo-Durán B. Atopic dermatitis in adults: A diagnostic challenge. J Investig Allergol Clin Immunol. 2017;27:78-88.
3. Sicras-Mainar A, Navarro-Artieda R, Sánchez L, Sastre J. Prevalence of severe atopic dermatitis in adults in 3 areas of Spain. J Invest Allergol Clin Immunol. 2018;28:195-7.

4. Barroso B, Vera-Berrios RN, Rial JM, Fariña-Sabaris MC, Santos LC, Sastre J. Prevalence of severe atopic dermatitis in adults and children in a health area of Madrid, Spain. J Invest Allergol Clin Immunol. 2019;29:77-9.

5. Lopes C, Rocha L, Sokhatska O, Soares J, Tavaria F, Correia O, et al. Filaggrin polymorphism Pro478Ser is associated with the severity of atopic dermatitis and colonization by Staphylococcal aureus. J Invest Allergol Clin Immunol. 2016;26:48-72.

6. Lopes C, Pinto L, Leite C, Delgado L, Moreira A, Lourinho I. Personality traits may influence the severity of atopic dermatitis in adult patients: A pilot study. J Invest Allergol Clin Immunol. 2016;26:198-9.

7. Bieber T. Atopic dermatitis. Ann Dermatol. 2010;22:125-37.

8. Nutten S. Atopic dermatitis: Global epidemiology and risk factors. Ann Nutr Metab. 2015;66:8-16.

9. Garmhausen D, Hagemann T, Bieber T, Dimitriou I, Fimmers $R$, Diepgen $T$, et al. Characterization of different courses of atopic dermatitis in adolescent and adult patients. Allergy. 2013:68:498-506.

10. de Frutos FO, Torrelo A, de Lucas R, González MA, Alomare $A$, Vera $A$, et al. Dermatitis atópica desde la perspectiva del paciente: desencadenantes, cumplimiento de las recomendaciones médicas y control de la enfermedad. Estudio DATOP. Actas Dermosifiliogr. 2014;105:487-96.

11. Bertanha F, Nelumba EJP, Freiberg AK, Samorano LP, Festa Neto C. Profile of patients admitted to a triage dermatology clinic at a tertiary hospital in São Paulo, Brazil. An Bras Dermatol. 2016:91:318-25.

12. Tejada CS, Mendoza-Sassi RA, Almeida Jr HL, Figueiredo PN, Tejada VFS. Impact on the quality of life of dermatological patients in southern Brazil. An Bras Dermatol. 2011;86:111321.

13. Orfali RL, Shimizu MM, Takaola R, Zaniboni MC, Ishizaki AS, Costa AA, et al. Atopic dermatitis in adults: clinical and epidemiological considerations. Rev Assoc Médica Bras. 2013;59:270-5.

14. Reguiaï Z. Dermatite atopique de I'adulte: présentation clinique, complications et comorbidités. Vol. 144, VS15-VS22 (Elsevier Masson, 2017).

15. Leung DYM, Guttman-Yassky E. Deciphering the complexities of atopic dermatitis: Shifting paradigms in treatment approaches. J Allergy Clin Immunol. 2014;134:769-79.

16. Antunes AA, Solé $D$, Carvalho VO, Kiszewski Bau AE, Kuschnir FC, Mallozi CM, et al. Updated practical guide on atopic dermatitis - Part I: Etiopathogenesis, clinical features, and diagnosis. Joint position paper of the Brazilian Association of Allergy and Immunology and the Brazilian Society of Pediatrics. Arq Asma Alerg Imunol. 2017;1:131-56 [Portuguese].

17. Aoki V, Lorenzini D, Orfali RL, Zaniboni MC, Oliveira ZNP, Rivitti-Machado MC, et al. Consensus on the therapeutic management of atopic dermatitis - Brazilian Society of Dermatology. An Bras Dermatol. 2019;94(2 Suppl 1):67-75.

18. Sala-Cunill $A$, Lazaro M, Herráez L, Quiñones MD, Moro-Moro M, Sanchez I, On behalf of the Skin Allergy Committee of Spanish Society of Allergy and Clinical Immunology (SEAIC). Basic skin care and topical therapies for atopic dermatitis: 
Essential approaches and beyond. J Invest Allergol Clin Immunol. 2018;28:379-91.

19. Carvalho VO, Solé D, Antunes AA, Kiszewski Bau AE, Kuschnir FC, Mallozi MC, et al. Updated practical guide on atopic dermatitis - Part II: treatment approach. Joint position paper of the Brazilian Association of Allergy and Immunology and the Brazilian Society of Pediatrics. Arq Asma Alerg Imunol 2017;1:157-82 [Portuguese].

20. Megna M, Napolitano M, Patruno C, Patruno C, Villani A, Balato $A$, et al. Systemic treatment of adult atopic dermatitis: A review. Dermatol Ther. 2017;7:1-23.

21. Severity scoring of atopic dermatitis: the SCORAD index. Consensus report of the European Task Force on Atopic Dermatitis. Dermatology. 1993;186:23-31.

22. Hanifin JM, Thurston M, Omoto M, Cherill R, Tofte SJ, Graeber $M$. The eczema area and severity index (EASI): assessment of reliability in atopic dermatitis. Exp Dermatol. 2001;10:11-8.

23. Barbier N, Paul C, Luger T, Allen R, De Prost Y, Papp K, et al. Validation of the Eczema Area and Severity Index for atopic dermatitis in a cohort of 1550 patients from the pimecrolimus cream $1 \%$ randomized controlled clinical trials programme. $\mathrm{Br}$ J Dermatol. 2004;150:96-102.

24. Leshem Y, Hajar T, Hanifin J, Simpson E. What the Eczema Area and Severity Index score tells us about the severity of atopic dermatitis: An interpretability study. $\mathrm{Br} J$ Dermatol. 2015;172:1353-7.

25. The Eczema Area and Severity Index (EASI) guidance v3 January 2017

26. Brunner PM, Guttman-Yassky E, Leung DY. The immunology of atopic dermatitis and its reversibility with broad-spectrum and targeted therapies. JAllergy Clin Immunol. 2017;139:S65-S76.

27. Gandhi NA, Bennett BL, Graham NM, Pirozzi G, Stahl N, Yancopoulos GD. Targeting key proximal drivers of type 2 inflammation in disease. Nat Rev Drug Discov. 2016;15:35.

28. Abuabara K, Yu A, Okhovat J, Allen I, Langan S. The prevalence of atopic dermatitis beyond childhood: a systematic review and meta-analysis of longitudinal studies. Allergy. 2018;73:696704.

29. Arima K, Gupta S, Gadkari A, Hiragun T, Kono T, Katayama I, et al. Burden of atopic dermatitis in Japanese adults: analysis of data from the 2013 National Health and Wellness Survey. J Dermatol. 2018;45:390-6.

30. Simpson EL, Bieber T, Eckert L, Wu R, Ardeleanu M, Graham $N M$, et al. Patient burden of moderate to severe atopic dermatitis $(A D)$ : insights from a phase $2 b$ clinical trial of dupilumab in adults. J Am Acad Dermatol. 2016;74:491-8.

31. Mortz C, Andersen K, Dellgren C, Barington T, Bindslev-Jensen C. Atopic dermatitis from adolescence to adulthood in the TOACS cohort: Prevalence, persistence and comorbidities. Allergy.2015;70:836-45.

32. Eckert L, Gupta S, Amand C, Gadkari A, Mahajan P, Gelfand JM. Impact of atopic dermatitis on health-related quality of life and productivity in adults in the United States: An analysis using the National Health and Wellness Survey. J Am Acad Dermatol.2017;77:274-9.

33. Megna M, Patruno C, Balato A, Rongioletti F, Stingeni L, Balato $\mathrm{N}$, et al. Italian Adult Atopic Dermatitis Study Group. An Italian multicentre study on adult atopic dermatitis: Persistent versus adult-onset disease. Arch Dermatol Res. 2017;309:443-52.

34. Geldsetzer P, Manne-Goehler J, Marcus ME, Ebert C, Zhumadilov Z, Wesseh CS, et al. The state of hypertension care in 44 low-income and middle-income countries: a crosssectional study of nationally representative individual-level data from 1.1 million adults. Lancet. 2019:394:652-62.

35. Lamelas P, Diaz R, Orlandini A, Avezum A, Oliveira G, Mattos $A$, et al. Prevalence, awareness, treatment and control of hypertension in rural and urban communities in Latin American countries. J Hypertens. 2019;37:1813-21

36. Picon RV, Fuchs FD, Moreira LB, Riegel G, Fuchs SC. Trends in prevalence of hypertension in Brazil: a systematic review with meta-analysis. PLoS One. 2012;7(10):e48255

37. Son JH, Chung BY, Kim HO, Park CW. Clinical features of atopic dermatitis in adults are different according to onset. J Korean Med Sci. 2017:32:1360-6.

38. Wang X, Shi XD, Li LF, Zhou P, Shen YW, Song QK. Prevalence and clinical features of adult atopic dermatitis in tertiary hospitals of China. Medicine (Baltimore). 2017;96:e6317.

39. Shrestha S, Miao R, Wang L, Chao J, Yuce H, Wei W. Burden of atopic dermatitis in the United States: analysis of healthcare claims data in the commercial, Medicare, and Medi-Cal databases. Adv Ther. 2017;34:1989-2006.

40. Corrêa-Fissmer $M$, Mendonça $M G$, Martins AH, Galato D. Prevalence of self-medication for skin diseases: a systematic review. An Bras Dermatol. 2014;89:626-30.

41. Orfali RL, Zaniboni MC, Aoki V. Profile of skin barrier proteins and cytokines in adults with atopic dermatitis. $\mathrm{G}$ Ital Dermatol Venereol. 2017;152:140-7.

42. Moreno AS, McPhee R, Arruda LK, Howell MD. Targeting the T helper 2 inflammatory axis in atopic dermatitis. Int Arch Allergy Immunol. 2016;17:71-80.

Manuscript received August 1, 2019; accepted for publication January 7, 2020.

\section{Karla Arruda}

Ribeirão Preto Medical School

Av. Bandeirantes, 3900

Ribeirão Preto, SP 14049-900, Brazil

E-mail: karla@fmrp.usp.br 